\begin{tabular}{|l|c|c|}
\hline & $\begin{array}{c}\text { ADIYAMAN ÜNIVERSITESI SOSYAL BiLiMLER ENSTITÜSÜ DERGISI } \\
\text { ISSN: } 1308-9196\end{array}$ \\
\cline { 2 - 3 } & Yıl : $5 \quad$ Sayı : $10 \quad$ Aralık 2012 \\
\hline
\end{tabular}

\title{
DETERMINATION ISSUES THAT PRIMARY TEACHERS ENCOUNTERED DURING PROBLEM POSING ACTIVITIES AND THEIR SOLUTION SUGGESTIONS: ELIMINATING PEDAGOGIC OBSTACLES
}

\author{
Çiğdem KILIÇ*
}

\begin{abstract}
Problem posing is one of the most important mathematical activities in mathematics education in primary schools as such posing problems allow both the students and teachers to gain benefits. The purpose of this study is to discover issues faced by primary teachers during problem posing applications in mathematics courses as well as determining solutions to these issues in primary schools. The data was collected using a questionnaire that consisted of two open-ended questions. A total of 352 teachers working in 24 primary schools participated in the study. The data was analyzed both using content and descriptive analyses methods. According to the results of the study it can be concluded that primary teachers experience both student-oriented and non-student-oriented issues, with the majority of the issues being student-oriented. Some of the primary teachers stated that they did not experience any issues related to problem-posing activities and some of them declared irrelevant issues. Teachers declared suggestios related to issues that they faced.
\end{abstract}

Key Words: Problem posing, primary teachers, issues and suggestions related to problem posing.

\footnotetext{
*Yrd.Doç.Dr. Mersin Üniversitesi Eğitim Fakültesi, İlköğretim Matematik Öğretmenliği, ckilic6@gmail.com
} 


\title{
SINIF ÖĞRETMENLERININ PROBLEM KURMA ETKINLIKLERi ILE İGILI OLARAK YAŞADIKLARI SORUNLAR VE BU SORUNLARA YÖNELIK ÇÖZÜM ÖNERILERI: PEDAGOJIK ENGELLERIN ORTADAN KALDIRILMASI
}

\begin{abstract}
Öz
Problem kurma matematik eğitiminde yer alan ve hem öğrencilere, hem de öğretmenlere katkıları olan önemli bir matematiksel etkinliktir. Bu çalışmanın amacı, sınıf öğretmenlerinin problem kurma etkinlikleri sırasında ne tür sorunlarla karşılaştıklarını ve bu sorunlara yönelik çözüm önerilerinin neler olduğunu araştırmaktır. Bu amaç doğrultusunda veriler iki açık-uçlu sorudan oluşan anket aracılığıyla toplanmıştır. 24 ilköğretim okulunda görev yapan sınıf öğretmenleri çalışmaya katılmış olup, toplam 352 sınıf öğretmenine açık uçlu anket uygulanmıştır. Araştırmadan elde edilen veriler, içerik ve betimsel analiz tekniği ile analiz edilmiştir. Araştırmadan elde edilen sonuçlara bakıldığında, öğretmenlerin belirttikleri sorunların, öğrenci merkezli olan ve olmayan olmasının yanı sıra, bazı öğretmenler problem kurma ile ilgili herhangi bir sorunla karşılaşmadıklarını belirtirlerken, bazıları da problem kurma ile ilgisi olmayan sorunlara değinmişlerdir. Öğretmenler problem kurma ile ilgili belirttikleri sorunlara yönelik çözüm önerileri de geliştirmişlerdir.
\end{abstract}

Anahtar Kelimeler: Problem kurma, sınıf öğretmenleri, problem kurma ile ilgili sorunlar ve öneriler.

\section{INTRODUCTION}

In classrooms, teachers have many duties and responsibilities outside of teaching, including helping their students adapt to the environment (Przybylska, 2011) as well as designing learning environments, instructional tasks and the curriculum. Hännikäinen and Rasku-Puttonen (2010) determined the roles of teachers in primary schools to be as follows.

"They encouraged children to participate, for instance, by supporting their engagement in joint activities and providing appropriate scaffolding according to the children's interests and needs. The teachers treated the children as worthy members of a community by listening to their proposals, posing questions, respecting their views and being interested 
in their world. These practices, which emphasize the importance of participation in classroom activities, reflect the efforts made by teachers to stimulate learning as interaction and engagement in collective meaning-making."

In Turkey, primary teachers follow a standard, national mathematics curriculum and, which, since 2005, has contained problem posing applications, especially in regard to the curriculum for first through fifth grades. For instance, the learning objectives of problem posing applications for first grade students utilize problems that require addition using natural numbers (MEB, 2009). Such applications often emphasize reallife problems in order to help the students develop problem-solving abilities (MEB, 2009). At this point, it is important to define problem posing. Problem posing is the creation of new problems or the reformulation of a given problem (Tichá \& Hošpesová, 2009a) in order to explore and solve a given situation (Silver, 1994). Another, similar definition was presented by Stoyanova and Ellerton (1996), who defined it as "as the process by which, on the basis of mathematical experience, students construct personal interpretations of concrete situations and formulate them as meaningful mathematical problems." Using the philosophical definition (Nixon-Ponder, 1995), it is a method leading to the development of pedagogical content knowledge (Tichá \& Hošpesová, 2009a) and a tool for studying cognitive processes (Mestre, 2002).

Using the above definitions, it can be seen that problem posing can be used to benefit both the students and teachers. For example, it helps the students to expand their understanding of mathematics and explore problems and solutions rather than focusing only on finding solutions (Stoyanova, 2003). It is also a tool that can be used to develop and strengthen the students' critical thinking skills (Nixon-Ponder, 1995), which can be used as an indicator of a deeper understanding of a concept (Rizvi, 2004). In regard to the benefits gained by teachers, problem posing tasks can help them gain insight into the way in which students construct their mathematical understanding and 
can be a useful assessment tool (Lin, 2004). Problem posing in elementary classrooms has a positive impact on their beliefs about mathematics and mathematics instruction (Barlow \& Cates, 2006). Problem posing involves many skills like formulate problems from every day and mathematical situations, use a proper approach for posing problems up to the mathematical situations and recognize relationships among different topics in mathematics (Abu-Elwan, 1999).

Several studies have focused on problem posing as it relates to students (Lowrie, 2002; Christou et al., 2004; Cankoy \& Darbaz, 2010), pre-service teachers (Lavy \& Bershadsky, 2003; Rizvi, 2004; Korkmaz \& Gür, 2006; Contreras, 2007; Toluk-Uçar, 2009; Luo, 2009; Tichá \& Hošpesová, 2009a; Işık, 2011) and teachers (Lin, 2004; Barlow \& Cates, 2006). The studies in which teachers are the sole participants tend to focus on their problem posing practices, beliefs and content knowledge of problem posing. Due to a lack of research on the issues faced by primary teachers as well as on suggestions regarding how to solve these issues, this study was undertaken.

\section{Benefits of problem posing activities}

Stoyanova (2003) stated that problem posing develops the students' understanding of mathematics and, their ability to understand is dependent upon the teachers' ability to incorporate problem posing activities in mathematics classrooms. Lowrie (2002) indicated that problem posing actions of students can be nurtured by teachers' actions. In order to help teachers better nurture the students' actions, one must learn what the teachers experience while teaching particular topics as well as the types of issues that they encounter while teaching. In order to provide an effective classroom environment, teachers should determine students' issues or obstacles and develop solutions that can be used to eliminate these issues. 
In addition, it is important to determine the pedagogic obstacles faced by teachers in order to enrich their pedagogical content (PCK) and subject matter knowledge, both of which are important aspects of a teacher's knowledge. According to Shulman (1987, p. 8), a teacher's knowledge is made up of many areas, including;

\begin{abstract}
"content knowledge; general pedagogical knowledge, with a special reference to those broad principles and strategies of classroom management and organization that appear to transcend subject matter; curriculum knowledge, with particular grasp of the materials and programs that serve as "tools of the trade" for teachers; pedagogical content knowledge, that special amalgam of content and pedagogy that is uniquely the province of teachers, their own special form of professional understanding; knowledge of learners and their characteristics; knowledge of educational contexts, ranging from the workings of the group or classroom, the governance and financing of school districts, to the character of communities and cultures; and knowledge of educational ends, purposes, and values, and their philosophical and historical grounds"
\end{abstract}

Shulman's model includes pedagody, content and students. Considering that a teacher's PCK affects his teaching, it is important to eliminate any issues that might prevent effective teaching such as issues related to problem posing. Furthermore, Park (2008) also indicated that elementary teachers had issues while implementing curriculum integration.

A review of the literature on problem posing shows scant resources on identifying issues faced by teachers in this area. Therefore, this study will aim to answer the following questions:

1. What types of issues related to problem posing activities are encountered by primary teachers?

2. What suggestions have been made by primary teachers in regard to overcoming these issues? 


\section{METHODOLOGY}

In this study, the opinions of primary teachers were used in order to determine the issues that they faced due to problem posing. Survey method was used to gather this information.

\subsection{Participants}

The participants were selected using a simple random sampling strategy so that all of the individuals in a defined population had an equal and independent chance of being selected (Gay et al., 2006). The sample of the study is representative of the 24 primary schools in Mersin, one of the most cosmopolitan cities in Turkey. The participants of the study consisted of primary teachers at state primary schools. All of the participants work at schools in the center of the city. These teachers taught between first and fifth grade. A total of 352 primary school teachers completed the open-ended questionnaire. The demographic information for the teachers is presented in Table 1.

Table 1. Demographic information about the primary school teachers who participated in this study.

\begin{tabular}{|l|l|l|l|}
\hline Characteristics & Sub-categories & Frequency & Percentage (\%) \\
\hline Gender & Male & 160 & 45.45 \\
& Female & 192 & 54.54 \\
\hline Years of teaching & $1-9$ years experience & 15 & 4.26 \\
& $10-19$ years experience & 36 & 10.22 \\
& 20-29 years experience & 138 & 39.20 \\
& 30 and more years experience & 163 & 46.30 \\
\hline Year taught & First grade & 68 & 19.31 \\
& Second grade & 76 & 21.59 \\
& Third grade & 68 & 19.31 \\
& Fourth grade & 72 & 20.45 \\
& Fifth grade & 68 & 19.31 \\
\hline Previously or currently & Yes & 0 & 0 \\
taking a seminar or & No & 352 & 100 \\
course about problem & & & \\
posing & & & \\
\hline
\end{tabular}


As seen in Table 1, the number of female and male teachers were relatively close. The majority of teachers had been teaching for at least 20 years. The teachers were equally distributed among the grade levels taught. None of the teachers had attended a seminar or course about problem posing.

First grade teachers were coded as $T_{1}$, second grade teachers as $T_{2}$, third grade teachers as $T_{3}$, fourth grade teachers as $T_{4}$ and fifth grade teachers as $T_{5}$. These codes were used while giving their written opinions related to the categories and subcategories.

\subsection{Data collection}

In order to understand the issues faced by the teachers, a two question open-ended questionnaire was used. In data collection process free writing on the theme (Kratochvilova, 2010) of problem posing issues and solutions regarding those issues were considered. As indicated in the study published by Arnon and Reichel (2007), open-ended questionnaires enable respondents to spontaneously and authentically reflect their points of view. In addition, as stated by Brown (2009); "the open-response items in the survey did not restrict the respondents to a set of answers, by allowing them to express their own ideas more fully in their own words. Such flexibility provided a relatively wide range of surprising responses, striking examples, and illustrative quotes, all of which added richness, depth and colour to the data" (Kızılaslan, 2012). Therefore, the researcher decided that the use of an open-ended questionnaire was a good way by which to explore the teachers' opinions. The questions presented in the questionnaire were as follows. Consisting of two openended questions in a questionnaire was presented to primary teachers in a written form and they were asked to fill the questions what they experienced during problem posing activity. In the questionnaire teachers were asked to write; "What types of issues have you encountered while using problem posing applications in your Adıyaman Üniversitesi Sosyal Bilimler Enstitüsü Dergisi, Yıl: 5, Sayı: 10, Aralık 2012 
classroom?" and "What suggestions do you have as to how to overcome these issues?" The teachers were given adequate time to respond to the questions.

\subsection{Data analyis}

The data was analyzed using the content analysis and descriptive methods. The analysis focused on determining and classifying the issues encountered and teachers' suggestions. The process is as follows. First, all of the responses provided were listed. Then, the written responses were classified according to similar categories and subcategories. These categories and sub-categories were determined gradually. These responses were organized into "student centered," "non-student centered" and an "other" category (Miles \& Huberman, 1994; Merriam, 1998). The frequencies of the sub-categories are given in parentheses as $f$. The teachers' views were given using " " in paragraphs after the categories. One mathematics education researcher coded data independently and for inter-rater reliability the formula of Miles and Huberman (1994) was used to calculate. It was calculated as $94 \%$ for the classification of issues and $93 \%$ for suggestions.

\section{RESULTS}

Three major issue dimensions emerged: student-oriented, non-student-oriented and other. Every dimension also presented sub-dimensions. Under student-oriented issues, the sub-categories were: affective characteristic, cognitive dimension, skill dimension and problem posing processes related to the students as declared by the participants. The non-student-oriented sub-categories were: exam system, curriculum, teacher, sources, time, classroom and family. In addition to these issues, some of participants shared declared issues related to problem solving, which are unrelated to problem posing, while other participants said they had not experienced any problem posing issues. These sub-categories fell under the other category. 
Determination Issues That Primary Teachers Encountered During Problem Posing Activities and Their Solution Suggestions: Eliminating Pedagogic Obstacles

Table 2. Issues faced by primary teachers.

\begin{tabular}{|l|l|c|c|}
\hline $\begin{array}{l}\text { Categories of } \\
\text { issues }\end{array}$ & Sub-categories & Frequency & Percentage (\%) \\
\hline \multirow{4}{*}{$\begin{array}{l}\text { Student-oriented } \\
\text { issues }\end{array}$} & Affective dimension & 52 & 12.09 \\
\cline { 2 - 4 } & Cognitive dimension & 19 & 4.41 \\
\cline { 2 - 4 } & Skill dimension & 90 & 20.93 \\
\cline { 2 - 4 } & Problem posing process & 71 & 16.51 \\
\hline \multirow{4}{*}{$\begin{array}{l}\text { Non-student- } \\
\text { oriented issues }\end{array}$} & Exam system & 1 & 0.23 \\
\cline { 2 - 4 } & Curriculum & 1 & 0.23 \\
\cline { 2 - 4 } & Teacher & 4 & 0.93 \\
\cline { 2 - 4 } & Sources & 20 & 4.65 \\
\cline { 2 - 4 } & Time & 27 & 6.27 \\
\cline { 2 - 4 } & Classroom & 20 & 4.65 \\
\cline { 2 - 4 } & Family & 6 & 1.39 \\
\hline \multirow{3}{*}{ Other } & Problem solving & 41 & 9.53 \\
\cline { 2 - 4 } & No problems & 78 & 18.13 \\
\hline Total & & 430 & 100 \\
\hline
\end{tabular}

\subsection{Student-oriented issues}

As seen in Table 2, a majority of the participants (20.93\%) stated that the skills of the students, such as not understanding what they read $(f=32)$, non-creative thinking $(f=6)$, no connection to real life applications $(f=20)$, expression disorders $(f=4)$, no reasoning $(f=6)$, unable to write a proper sentence $(f=12)$, not being able to estimate $(f=1)$, a lack of listening $(f=3)$ and not using numbers properly $(f=7)$, were major problems. The quotes below show how the participants reflected on the issues faced in the skill subcategories. Comments included "the students have some difficulties understanding what they read " $\left(\mathrm{T}_{2}\right)$, "because they are not creative in their daily lives, so they do not do creative thinking in problem posing" $\left(\mathrm{T}_{3}\right)$; "they had difficulty relating the activity to every day life applications" $\left(\mathrm{T}_{1}\right)$; "they can not connect the activities to reality. For instance, one student could say that an individual had a 25-year-old child, but was only nine-years-old" $\left(\mathrm{T}_{4}\right)$; "my students are in their first class and are having readingcomprehension problems" $\left(\mathrm{T}_{1}\right)$, "the students cannot reason" $\left(\mathrm{T}_{2}, \mathrm{~T}_{4}\right)$; "they cannot 
write what they think as a mathematical sentence" $\left(T_{1}, T_{2}, T_{4}\right)$; "some of the students cannot write what they think" $\left(\mathrm{T}_{5}\right)$; "some of the students lack listening skills" $\left(\mathrm{T}_{4}\right)$ and "some of the students do not use numbers effectively in problem posing" $\left(\mathrm{T}_{3}\right)$. The most common issue in this sub-category was the student's inability to understand what he read.

The second most often discussed sub-category was the problem posing process itself. Areas that caused problems included an inability to make a connection between given and wanted in their posed problems $(f=23)$, not translating knowledge to problem posing $(f=2)$, posing similar problems $(f=8)$, posing easy problems $(f=17)$, a lack of data in the posed problems $(f=4)$, complex relationships in the posed problems $(f=5)$, not using the data effectively $(f=6)$ and not mastering the subject $(f=6)$. Following are excerpts from the teachers' questionnaires: "some of them are unable to connect the relationships between the given and wanted" $\left(\mathrm{T}_{2}, \mathrm{~T}_{3}, \mathrm{~T}_{4}, \mathrm{~T}_{5}\right)$, "student can not use the information learned in posing problem" $\left(\mathrm{T}_{3}\right)$; "my students pose similar problems to those that they have posed previously" $\left(\mathrm{T}_{1}\right)$; "the students posed similar problems sometimes" $\left(\mathrm{T}_{3}\right)$; "very simple problems are posed by the students" $\left(\mathrm{T}_{4}\right)$; "the students pose very shortly, one step problems" $\left(\mathrm{T}_{5}\right)$; "there is data missing in the posed problem" $\left(\mathrm{T}_{5}\right)$; "the students have difficulty in using the data in problem posing" $\left(\mathrm{T}_{1}\right)$; "some of the students do not use the data given in a particular problem posing situation" $\left(\mathrm{T}_{2}\right)$ and "sometimes the students do not have enough knowledge to pose the problem" $\left(T_{3}\right)$. The most often discussed issue was a lack of ability to make a connection between the given and wanted in the posed problems.

The next important sub-category was the affective characteristics (12.09\%). These characteristics included distractibility $(f=8)$, not wanting to think $(f=9)$, an inability to express oneself $(f=12)$, difficulty in perception of problem posing situation $(f=14)$, not loving writing $(f=2)$, not willing to pose a problem $(f=3)$, fear of the solveability of 
posed problems $(f=3)$ and a lack of self-confidence $(f=1)$. Some of the teachers' responses were: "some of the students are easily distracted" $\left(T_{1}, T_{2}, T_{3}, T_{4}, T_{5}\right)$; "some of the students do not want to think in a wider perspective" $\left(\mathrm{T}_{2}\right)$; "some of the students do not want to think about anything so in that time I spend too much effort" $\left(\mathrm{T}_{3}\right)$; "the students have an inability to reflect upon their thoughts and feelings" $\left(T_{1}, T_{2}, T_{3}, T_{4}, T_{5}\right)$ "the students sometimes have difficulties in understanding" $\left(\mathrm{T}_{1}, \mathrm{~T}_{3}, \mathrm{~T}_{4}, \mathrm{~T}_{5}\right)$; "the students do not want to write the problem posing situation or the problem themselves" $\left(T_{2}, T_{3}\right)$ and "sometimes the children are not eager to participate" $\left(T_{2}, T_{3}\right)$. The most often commented on issues were the students inabilities to express themselves and having difficulty in perception of problem posing situation.

The issues related to the cognitive characteristics of the students were low. Only $4.41 \%$ of the participants stated that the students' cognitive characteristics, including a lack of a vocabulary $(f=13)$, lack of knowledge of the four mathematical operations $(f=5)$ and not creating whole problem $(f=1)$, caused issues. Some of the teachers' statements on these issues follow: "the students had issues because of their limited words" $\left(\mathrm{T}_{1}\right)$; "some of the students used very limited words, they could only use 20 or 30 words and no more" $\left(\mathrm{T}_{3}\right)$, "some of the students do not read books very often, so they had difficulty finding the right words to use in the problem posing" $\left(\mathrm{T}_{2}\right)$; and "they do not know the mathematical operations well" $\left(\mathrm{T}_{1}, \mathrm{~T}_{2}, \mathrm{~T}_{5}\right)$. Of the issues, the lack of a vocabulary received the highest number of mentions.

\subsection{Non-student-oriented issues}

Under non-student-oriented issue, one participant emphasized that the test-based examination system affects problem posing perception. Another participant stated that he encountered issues related to the curriculum. Four of the participants stated that they encountered issues regarding teachers, while two of the participants stated 
that they had difficulty helping the students grasp how to work on the problem posing. Two of the participants faced issues related to the learning objectives of problem posing. Four of the participants stated that being in crowded classrooms caused problems, while 16 participants stated that having students of different achievement levels within the same classroom caused issues. Six of the participants experienced issues related to the families of students. The sub-categories related to family were disinterest of the family $(f=3)$, education level of family $(f=2)$ and financial situation of the family $(f=1)$. Under non-student oriented issues percentage of time was the highest one among the other sub-dimensions of non-student oriented issues. 27 of the participants stated that they do not have enough time for problem posing applications. Teachers declared that "we don't have enough time to perform problem posing activities in classroom. Another issue was related to source. 13 teachers declared that there are not enough examples in textbooks and 7 declared that there are not enough teaching materials. Teachers views about source is like "inadequate teaching materials" $\left(\mathrm{T}_{4}\right)$, "not enough problem posing examples in textbooks" $\left(\mathrm{T}_{4}\right)$, "examples of problem posing in textbooks should be more simple to understand" $\left(T_{5}\right)$. Time is the most common issue for problem posing activities in classroom.

\subsection{Other}

Within the "other" category, $18.13 \%$ of the participants stated that they did not have any issues during the problem posing applications, while $9.53 \%$ of the participants stated that they had issues that centered around the students' abilities to problem solve, which is not directly related to problem posing. Examples of the comments include "not understanding and interpreting a problem" $\left(\mathrm{T}_{1}, \mathrm{~T}_{2}, \mathrm{~T}_{3}, \mathrm{~T}_{4}, \mathrm{~T}_{5}\right)$; "the students had some difficulty in translating the data into a picture" $\left(\mathrm{T}_{2}\right)$; "they had difficulty in understanding, devising and carrying out a plan that would lead to the evaluation of a problem" $\left(\mathrm{T}_{3}\right)$; and "the students do not want to draw a picture about 
Determination Issues That Primary Teachers Encountered During Problem Posing Activities and Their Solution Suggestions: Eliminating Pedagogic Obstacles

problem" $\left(\mathrm{T}_{4}\right)$. As seen from the Table 2, 78 teachers declared issues not related problem posing. Sugesstions made by teachers related to issues are given in Table3.

\section{4. Suggestions}

The suggestions made by the participants were categorized in accordance with the issues that they solved.

Table 3. Proposed suggestions by the participants

\begin{tabular}{|l|l|c|c|}
\hline \begin{tabular}{l} 
Categories $\begin{array}{l}\text { of } \\
\text { suggestions }\end{array}$ \\
\multirow{3}{*}{$\begin{array}{l}\text { Suggestions related } \\
\text { to student-oriented } \\
\text { issues }\end{array}$}
\end{tabular} & Sub-categories & Frequency & Percentage (\%) \\
\cline { 2 - 4 } & Cognitive dimension & 29 & 6.43 \\
\cline { 2 - 4 } & Skill dimension & 10 & 2.21 \\
\cline { 2 - 4 } & Problem posing process & 87 & 19.29 \\
\hline \multirow{4}{*}{$\begin{array}{l}\text { Suggestions related } \\
\text { to non-student- } \\
\text { oriented issues }\end{array}$} & Curriculum & 10 & 19.95 \\
\cline { 2 - 4 } & Teacher & 6 & 2.21 \\
\cline { 2 - 4 } & Sources & 35 & 1.33 \\
\cline { 2 - 4 } & Time & 27 & 7.76 \\
\cline { 2 - 4 } & Classroom & 19 & 5.98 \\
\cline { 2 - 4 } & Family & 19 & 4.21 \\
\hline Other & Irrelevant-problem solving & 41 & 9.21 \\
\cline { 2 - 4 } & $\begin{array}{l}\text { Did not encounter any } \\
\text { problems }\end{array}$ & 78 & 17.29 \\
\hline Total & & 451 & 100 \\
\hline
\end{tabular}

\subsection{Suggestions related to student-oriented issues}

As seen in Table 3, the highest number of suggestions (19.95\%) was how to solve issues related to the problem posing process. These suggestions include making concrete and visual studies ( $f=22)$, becoming an information society $(f=1)$, applying frequent problem posing studies in the classroom $(f=36)$, rewarding the students for the problems posed interestingly $(f=1)$, posing problems in relationship to new topics $(f=2)$, usin daily life situations for the problem posing situations $(f=1)$, examining Adıyaman Üniversitesi Sosyal Bilimler Enstitüsü Dergisi, Yıl: 5, Sayı: 10, Aralık 2012 
examples of problem posing $(f=1)$, posing simple problems at first $(f=5)$, carrying out problem posing activities in all lessons $(f=2)$, determining evaluation criteria for the posed problems $(f=1)$, solving posed problems $(f=1)$, analyzing posed problems $(f=1)$, using drama $(f=2)$, using a game-based approach $(f=3)$, performing activities regarding the socio-economic status of pupils $(f=4)$, perambulating $(f=1)$, solving different problems $(f=2)$, teaching the problem solving process $(f=2)$ and performing problem posing activities that fill in the blanks related to problem posimg situation $(f=2)$. Examples of the comments presented by the participants are as follows: "problem posing should be taught via games" $\left(\mathrm{T}_{1}, \mathrm{~T}_{4}\right)$, "examples of the posed problems should be examined" $\left(\mathrm{T}_{3}\right)$, "the observation method should be used" $\left(\mathrm{T}_{3}\right)$, "visual materials should be used in the classroom" $\left(\mathrm{T}_{4}\right)$, "different problems should be posed in accordance with the appropriate level for each students" $\left(\mathrm{T}_{4}\right)$, "the scope of problem posing must be specified thoroughly" $\left(\mathrm{T}_{5}\right)$, "filling the blanks studies can be done" $\left(\mathrm{T}_{4}\right)$ and "the students should be encouraged to set up the problem" $\left(\mathrm{T}_{3}\right)$. The most often suggested solution was to applying problem posing activities in the classrooms.

The next most often suggestions which wer made focused on the skills of the students (19.29\%). These suggestions included instilling in them the habit of reading $(f=14)$, giving place writing and understanding work $(f=7)$, encouraging them to develop questions related to every day life applications ( $f=26)$, working with them on speaking and understanding studies in Turkish lesson $(f=9)$ and doing work that involves plenty of reading $(\mathrm{f}=31)$. Examples of the comments include: "in Turkish courses, there should be reading, comprehension and writing studies" $\left(\mathrm{T}_{5}\right)$; "activities in reading and comprehension should be increased" $\left(\mathrm{T}_{1}, \mathrm{~T}_{2}, \mathrm{~T}_{3}, \mathrm{T5}\right)$; "students should read a lot of books" ( $\left.\mathrm{T}_{1}, \mathrm{~T}_{2}, \mathrm{~T}_{3}, \mathrm{~T}_{4}, \mathrm{~T}_{5}\right)$; and "attention should be paid to developing questions related to every day life" $\left(\mathrm{T}_{1}, \mathrm{~T}_{2}, \mathrm{~T}_{3}, \mathrm{~T}_{4}, \mathrm{~T}_{5}\right)$. The most often suggested solution was to encourage the students to develop questions related to every day life applications. 
The suggestions pertaining to students' affective characteristics (6.43\%) were eliminating attention clutter $(f=5)$, improving the students' self-confidence $(f=1)$, expanding encouragement by giving examples of the posed problems $(f=1)$, endearing mathematics $(f=6)$, improving the student's ability of expressing themselves $(f=8)$, providing to think $(f=5)$, being active in the classroom $(f=3)$. Some of the statements made by the participants were "the students' abilities of expressing themselves in the classroom can be improved by giving them the right to speak" $\left(\mathrm{T}_{1}, \mathrm{~T}_{2}, \mathrm{~T}_{3}, \mathrm{~T}_{4}, \mathrm{~T}_{5}\right)$, "remove distracting activities" ( $\left.\mathrm{T}_{4}, \mathrm{~T}_{5}\right)$, "mathematics should be endeared" $\left(\mathrm{T}_{4}\right)$ and "students need to popularize mathematics lessons" $\left(T_{5}\right)$. The most often expressed solution was to allow the students to express themselves more.

The suggestions related to the cognitive domain (2.21\%) were as follow: extending the students' vocabulary $(f=4)$; using different environments, such as the cinema to develop the students' vocabulary, $(f=2)$; improving the students' mental powers $(f=2)$, improving the students' knowledge of the four arithmetical operations $(f=1)$; and gaining knowledge of the numbers $(f=1)$. Some examples of the statements by the teachers are "vocabulary learning activities should be performed" $\left(T_{1}, T_{2}, T_{3}, T_{5}\right)$, "students should read a lot of books" and "they should go to the cinema" $\left(\mathrm{T}_{1}, \mathrm{~T}_{2}\right)$. The most often suggestion made was to extend the students' vocabulary.

\subsection{Suggestions related to non-student-oriented issues}

The most often discussed issue, in regard to solutions, in the non-student-oriented category was sources (7.76\%). These solutions included having more examples in the textbooks ( $f=21)$, using technological products and the Internet in the classroom $(f=2)$, having a $C D$ explaining problem posing in the textbooks $(f=1)$, using written and visual teaching materials $(f=9)$ and utilizing student workbooks $(f=2)$. Some of the statements made by the participants are as follow: "there should be enough materials in the classroom" $\left(\mathrm{T}_{1}, \mathrm{~T}_{2}\right)$, "have more activities in the textbooks" $\left(\mathrm{T}_{1}, \mathrm{~T}_{2}, \mathrm{~T}_{3}, \mathrm{~T}_{4}, \mathrm{~T}_{5}\right)$, "provide Adıyaman Üniversitesi Sosyal Bilimler Enstitüsü Dergisi, Yıl: 5, Sayı: 10, Aralık 2012 
adequate tools in the classroom" $\left(\mathrm{T}_{3}\right)$, "the textbooks should emphasized more problem posing activities" $\left(\mathrm{T}_{2}, \mathrm{~T}_{5}\right)$, "the textbooks should be prepared according to students' living environment" $\left(\mathrm{T}_{4}\right)$ and "problem posing should be taught as a separate unit" $\left(\mathrm{T}_{5}\right)$. The most often suggestion made was to have more problem posing examples in the textbooks.

Another area that garnered many suggestions was time (5.98\%), especially in regard to the time spent on mathematics lessons, which they felt should be increased $(f=27)$. The students' families (4.21\%) were another area that garnered several suggestions. Some of the suggestions were: "families should give some responsibility to their children" $\left(\mathrm{T}_{2}\right.$, $\left.\mathrm{T}_{3}, \mathrm{~T}_{5}\right)$, "families should go shopping with their children" $\left(\mathrm{T}_{1}, \mathrm{~T}_{2}\right)$ and "families should read books to their students" $\left(\mathrm{T}_{4}\right)$. A few suggestions were made as to how to improve the classroom (4.21\%). These suggestions included "establishing level classes" $\left(\mathrm{T}_{3}\right)$, "reducing class sizes" $\left(\mathrm{T}_{1}, \mathrm{~T}_{2}, \mathrm{~T}_{3}, \mathrm{~T}_{4}, \mathrm{~T}_{5}\right)$ and "having more mathematics classrooms" $\left(T_{2}\right)$. Suggestion is about the curriculum $(2.21 \%)$ and the teacher $(1.33 \%)$ which were coded under solutions related non student- oriented. Suggestions about curriculum can be given like "some of the topics should be removed from the curriculum" $\left(\mathrm{T}_{4}\right)$ and "program should include plenty of examples of problem posing" $\left(\mathrm{T}_{5}\right)$. Increasing number of mathematics lessons suggested by participants overwhelming.

\subsection{Other}

Under "other" category, the participants provided suggestions focused on problem solving $(f=41)$, which is outside of the realm of this study. Other participants $(f=78)$ did not have any suggestions related to problem posing. 


\section{DISCUSSION AND CONCLUSION}

Teachers should consider incorporating problem posing activities into their classrooms in order to positively influence their beliefs about mathematics and mathematics instruction (Barlow \& Cates, 2006). Such an incorporation could also have a significant impact on the students as well (Stoyanova, 2003; Nixon-Ponder, 1995; Rizvi, 2004). When endorsing such incorporation, it is important to understand the issues faced by teachers in regard to problem posing activities in order to help solve these issues and make the teachers more effective. The issues presented by the participants included the affective and cognitive characteristics and skills of the students as well as their performances in regard to problem posing. The majority of these issues were directly related to student-oriented issues, which can be attributed to the fact that posing problems requires many skills, such as formulating and recognizing relationships (AbuElwan, 1999). As indicated in Mestre's study (2002) on problem posing, it is a tool used to study cognitive processes and, as such, can be used to reveal of students' cognitive obstacle asking their teachers. Cognitive processes are necessary when attempting to solve mathematical equations; therefore, in order to better succeed in problem posing, students' cognitive functions need to be better developed. There is an evident that besides cognitive factors affective factors effect students' mathematical achievement. Mathematical achievement is not only a function of cognitive factors but it also points to the importance of affective factors for the development of mathematical achievement (Lebens, et al., 2011). For that reason students' affective and cognitve factors should be developed.

Other issues raised by the participants were not directly related to the students. The main issue was the students' families. Ways to combat family inactivity with the student would be to design extracurricular activities aimed at helping families realize the important of problem posing (Wang, 2004). Such activities would also help engage the parents in the decision-making process at their child's school. Another important 
issue was classroom size, which is closely tied to achievement levels within a classroom. As indicated by Olatunde (2010), the larger the mathematics class size, the lower the performance of the students. Therefore, it is recommended that the students in the class not exceed 30.

Future researches should focus on how problem solving and problem posing are related, especially as to how they are viewed by teachers since several teachers stated that they did not have any problem posing issues, but did have problem solving issues. For that reason teachers' subject matter knowledge being one of the teacher knowledge component (Shulman, 1987) should be investigated in terms of problem posing deeply. In order to effectively use problem posing as an assessment tool (Lin, 2004) and teaching strategy (Stoyanova, 2003) in primary school classrooms, teachers must be educated in the content. To this end, primary teachers' pedagogical competences in mathematics education (Tichá \& Hošpesová, 2009b) should be investigated and, according to the results, be encouraged to attend educational seminars, workshops or programs on the areas in which they are lacking knowledge. Acquisition of mathematical concepts with a distinction between concept images and concept definitions (Gutiérrez \& Jaime, 1999) can be used to reveal difficulties and errors related to the concept of problem posing.

Observations can be performed actively in order to understand what kind of issues occured in classrooms and consequently improvement of classroom practices can take placed. Besides observations, in-depth interviews can be conducted with teachers and students. That study can be done regarding primary teachers' teaching experience. As suggested by teachers in the study different teaching methods like drama-based, game-based approaches and visual materials can be implemented in classrooms. As indicated in the study of Park (2008) it is important to provide classroom teachers with more accessible guidelines grounded in their practical experiences of designing and 
implementing integrated curricula. Moreover, students should read more and besides reading activity, speaking, writing activities should be performed and students motivated to express themselves. Families should help teachers for work of problem posing and hours of problem posing should be increased. Teachers' problem posing perceptions and self efficacy beliefs can be investigated.

\section{REFERENCES}

Abu-Elwan, R. (1999). "The Development of Mathematical Problem Posing Skills for Prospective Middle School Teachers." In Mina, F.\& Rogerson, A. (Eds.) Paper Presented at The Proceedings of The International Conference on Mathematical Education into The 21st Century: Socital Challenges, Issues and Approaches, Cairo, Egypt. (pp.1-8).

Arnon, S. \& Reichel, N. (2007). "Who Is The Ideal Teacher? Am I? Similarity and Difference in Perception of Students of Education Regarding The Qualities of A Good Teacher and of Their Own Qualities As Teachers." Teachers And Teaching: Theory and Practice, 13 (5): 441-464.

Barlow, A. T. \& Cates, J. M. (2006). “The Impact of Problem Posing on Elementary Teachers' Beliefs about Mathematics and Mathematics Teaching." School Science and Mathematics, 106 (2): 64-73.

Cankoy, O. \& Darbaz, S. (2010). “Problem Kurma Temelli Problem Çözme Öğretiminin Problemi Anlama Başarısına Etkisi." Hacettepe University Education Faculty Journal, 38, 11-24.

Christou, C., Mousoulides, N., Pittalis M., Pitta-Pantazi, D.\&Sriraman, B. (2005). “An Empirical Taxonomy of Problem Posing Process." ZDM, 37 (3):149-158.

Contreras, J. (2007). “Unraveling The Mystery of The Origin of Mathematical Problems: Using A Problem-Posing Framework with Prospective Mathematics Teachers. “ The Mathematics Educator, 17(2):15-23. 
Gay, L. R., Mills, G. E. \& Airasian, P. (2006). Educational Research: Competencies For Analysis And Applications.(8th Ed.). New Jersey: Pearson Prentice Hall.

Gutiérrez, A. \& Jaime A. (1999). "Preservice Primary Teachers' Understanding of The Concept of Altitude of A Triangle." Journal Of Mathematics Teacher Education, 2(3):253-275.

Hännikäinen \& Rasku-Puttonen (2010). “Promoting Children's Participation: The Role of Teachers in Preschool and Primary School Learning Sessions." Early Years, 30(2):147-160.

Işık, C. (2011). “Conceptual Analysis of Multiplication and Division in Fractions Posed By Prservice Elementary Mathematics Teachers." Hacettepe University Journal Of Education Faculty, 41: 231-243.

Kızılaslan, ì. (2012). "Teaching in Rural Turkey: Pre-Service Teacher Perspectives." European Journal Of Teacher Education, 35(2): 243-254.

Korkmaz, E.\&Gür, H. (2006). “Öğretmen Adaylarının Problem Kurma Becerilerinin Belirlenmesi. [Determining Of Prospective Teachers' Problem Posing Skills]." Balıkesir Üniversitesi Fen Bilimleri Enstitüsü Dergisi, 8 (1):64-74.

Kratochvilova, J. (2010). "The Teacher's Conception of Project Based Teaching." The New Educational Review, 21(2):31-41.

Lavy, I.\&Bershadsky, I. (2003). "Problem Posing Via "What if Not?" Strategy in Solid Geometry-A Case Study." Journal of Mathematical Behavior, 22: 369-387.

Lebens, M. Graff, M. \& Mayer, P. (2011). "The Affective Dimensions of Mathematical Difficulties in Schoolchildren." Education Research International, 1-13.

Lin, P., L. (2004). "Supporting Teachers on Designing Problem-Posing Tasks As A Tool Of Assessment To Understand Students' Mathematical Learning." In (Eds.) Paper Presented in Proceedings of The 28th Conference of The International Group for The Psychology of Mathematics Education, (Pp.3-257-264). 
Lowrie, T. (2002). “Designing A Framework for Problem Posing: Young Children Generating Open-Ended Tasks." Contemporary Issues In Early Childhood, 3 (3): 354-64.

Luo, F. (2009). “Evaluating The Effectiveness and Insights of Pre-Service Elementary Teachers' Abilities to Construct Word Problems for Fraction Multiplication." Journal Of Mathematics Education, 2(1):83-98.

MEB (2009). Ilköğretim Matematik Dersi 1-5.Sınıflar Öğretim Programı. [Primary School Mathematics Curriculum (1.-5 Grades)]. Ankara Devlet Kitapları Basımevi.

Merriam, S. B. (1998). Qualitative Research and Case Study Applications in Education. (1st Ed.).San Francisso: Jossey-Bass.

Mestre, P. J. (2002). “Probing Adults' Conceptual Understanding and Transfer of Learning Via Problem Posing." Applied Developmental Psychology, 23: 9-50.

Miles, M. \& Huberman, M. (1994). An Expanded Sourcebook Qualitative Data Analysis (2 Th Ed.).California: Sage Publications.

Nixon-Ponder, S. (1995). “Using Problem Posing Dialogue in Adult Literacy Education. Teacher To Teacher." Adult Learning, 7(2): 10-12.

Olatunde, Y. P. (2010). “Class Size and Students' Mathematics Achievement of Senior Secondary Schools in Southwestern Nigeria." The Social Sciences, 5(2):108-112.

Park, M. (2008). “Implementing Curriculum Integration: The Experiences of Korean Elementary Teachers." Asia Pacific Education Review, 9 (3):308-319.

Przybylska, I. (2011). "Teachers' Role Perception." The New Educational Review, 26(4):85-96.

Rizvi, N. F. (2004). "Prospective Teachers' Ability to Pose Word Problems." International Journal For Mathematics Teaching And Learning, 12: 1-22.

Silver, E. A. (1994). "On Mathematical Problem Posing." For The Learning Of Mathematics, 14(1):19-28.

Shulman, L. S. (1987). "Knowledge and Teaching: Foundations Of The New Reform." Harvard Educational Review, 57: 1-22. 
Stoyanova, E. \& Ellerton, N. F. (1996). A Framework for Research into Students' Problem Posing in School Mathematics. In P. Clarkson (Ed.),Technology in Mathematics Education (Pp.518-525). Melbourne: Mathematics Education Research Group of Australasia.

Stoyanova, E. (2003). “Extending Students' Understanding of Mathematics Via Problem Posing." The Australian Mathematics Teacher, 59(2): 32-40.

Tichá M.\& Hošpesová, A. (2009a). "Problem Posing and Development of Pedagogical Content Knowledge in Pre-Service Teacher Training." In (Eds.) Paper Presented At The Proceedings Of CERME 6, Lyon, France. (Pp.1941-1950).

Tichá, A. \& Hošpesová, M. (2009b). “Following The Path of The Teacher's Development." The New Educational Review, 17(1):212-232.

Toluk- Uçar, Z. (2009). “Developing Pre-Service Teachers Understanding of Fractions Through Problem Posing." Teaching and Teacher Education, 25: 166-175.

Wang, D. B. (2004). "Family Background Factors and Mathematics Success: A Comparison of Chinese and US Students." International Journal Of Educational Research, 41(1):40-54. 